\title{
ANALISIS INTERKULTURAL TUTURAN BAHASA JERMAN DALAM BUKU AJAR DI PERGURUAN TINGGI
}

\author{
Sudarmaji, Pratomo Widodo, dan Akbar K Setiawan \\ FBS Universitas Negeri Yogyakarta \\ email: a_sudarmaji@yahoo.com
}

\begin{abstract}
Abstrak
Penelitian ini bertujuan mengindentifikasi tuturan-tuturan interkultural yang terdapat dalam buku ajar bahasa Jerman di perguruan tinggi. Sumber data adalah buku ajar bahasa Jerman Studio d A1, A2, dan B2 sebagai buku ajar pokok. Pengumpulan data menggunakan teknik simak dan baca markah. Analisis data menggunakan teknik analisis isi dan padan ekstralingual. Hasil penelitian sebagai berikut. Pertama, tema interkultural yang ditemukan berkaitan dengan makanan, pakaian, pekerjaan, sistem perkawinan, pandangan terhadap waktu, sopan santun, tradisi, aturan, dan bahasa. Kedua, faktor penyebab perbedaan, yaitu musim, makanan pokok, ideologi (agama), sistem bahasa, tingkat kesejahteraan, dan sejarah bangsa. Ketiga, faktor pengetahuan terhadap budaya Jerman merupakan modal penting dalam memahami tuturan interkultur.
\end{abstract}

Kata kunci: interkultural, interkulturelle Germanistik, buku ajar bahasa Jerman

\section{AN INTERCULTURAL ANALYSIS OF GERMAN UTTERANCES IN HIGHER EDUCATION COURSE BOOKS}

\begin{abstract}
This study aims to identify intercultural utterances in German course books for higher education. The data sources were German course books, namely Studio d A1, A2, and B2 as primary course books. The data were collected through marked listening and reading techniques. They were analyzed by means of content analysis and extralingual correspondence. The findings are as follows. First, the intercultural themes are related to food, clothing, jobs, marriage systems, perceptions of time, politeness, traditions, regulations, and languages. Second, the factors causing differences include seasons, staple foods, ideologies (religions), language systems, welfare levels, and nations' histories. Third, the factor of understanding of the German culture is an important foundation to understand intercultural utterances.
\end{abstract}

Keywords: intercultural, interkulturelle Germanistik, German course books

\section{PENDAHULUAN}

Bahasa dan budaya merupakan dua hal yang tidak dapat dipisahkan. Bahasa adalah produk atau bagian dari budaya. Bahasa lahir dari sebuah komunitas budaya tertentu. Ia diciptakan oleh orang-orang yang berada dalam komunitas tersebut yang juga mempunyai budaya khusus di lingkungan itu. Secara otomatis ungkapan yang digunakan untuk mengekspresikan sesuatu sangatlah terkait dengan budaya setempat. Dengan demikian bahasa merupakan bagian integral dari suatu bu- daya. Oleh karena itu, adalah suatu hal yang mustahil untuk mempelajari suatu bahasa asing tanpa mengaitkan dengan budayanya, karena bahasa itu sendiri merupakan alat ekspresi budaya. Namun demikian, adanya perbedaan budaya antara budaya sendiri dengan budaya dari bahasa (asing) yang dipelajari tidak jarang menimbulkan kesulitan atau bahkan kesalahpahaman. Akibat perbedaan budaya tersebut sering kali menyebabkan seorang pembelajar tidak bisa memahami sepenuhnya ungkapan-ungkapan dari 
bahasa asing yang sedang dipelajarinya. Berikut beberapa contoh yang mengilustrasikan situasi tersebut.

Ein Mann, der Herrn Klange nicht gesehen hatte, begrüßte ihn mit den Wörtern: "Sie haben sich gar nicht verändert" Oh, sagte Herr K und erbleichte. (Studio d B1:19) Seorang laki-laki menyapa orang lain yang lama tidak bertemu dengan ungkapan" anda sama sekali tidak berubah" dan orang tersebut menjadi pucat.

Ditinjau dari sisi kebahasaan, tuturan "Sie haben sich gar nicht veraendert" tidaklah sulit untuk dipahami secara harfiah, yaitu 'anda sama sekali tidak berubah'. Namun dari sisi penggunaannya kalimat tersebut mengacu pada makna sosial orang Jerman. Dalam konteks budaya Jerman tuturan tersebut dianggap tidak sopan dan menyinggung perasaan orang yang diajak bicara. Sementara dalam konteks budaya Indonesia tuturan tersebut adalah ungkapan perasaan senang seseorang yang lama tidak bertemu dan berseloroh dengan ungkapan tersebut. Kesulitan untuk memahami sebuah kalimat semacam itu kerap ditemui, tidak saja hanya pada hal-hal yang menyangkut masalah sosial, namun juga yang disebabkan oleh adanya perbedaan cara pandang atau cara berpikir antara orang Jerman dan orang Indonesia (Engel, 1991).

Berdasarkan masalah di atas, muncullah disiplin ilmu yang mencoba memberikan solusi atas berbagai masalah yang ditimbulkan akibat dari komunikasi budaya tersebut. Germanistik atau yang dalam bahasa Inggris juga lazim disebut sebagai German studies merupakan the field of humanities that researches, documents, and disseminates German language and literature in both its historic and present forms (http:// en.wikipedia.org/wiki/German_studies). Dalam pengertian yang lama Germanistik juga sering dikaitkan dengan studi Filologi
Jerman (Deutsche Philologie). Sementara itu, Germanistik modern mencakup tiga bidang kajian utama, yaitu linguistik Jerman (Germanistische Linguistik), sastra Jerman (Germanistische Literaturwissenschaft), dan media (Medienwissenschaft (http:// de.wikipedia.org/wiki/Germanistik). Kajian linguistik meliputi studi linguistik sinkronis dan diakronis, kajian sastra menjangkau dari sastra lama hingga sastra modern, sedangkan kajian media menyoroti keterkaitan antara komunikasi, budaya, dan media; yang salah satu contoh kajiannya adalah bidang sinema atau Filmphilologie (Widodo, 2011).

Dalam perkembangan selanjutnya muncul subdisiplin baru yang dikenal dengan istilah Auslandsgermanistik (Germanistik luar negeri), yang kurang lebih bisa dipahami sebagai Germanistik dari perspektif penutur asing (non native). Istilah Auslandsgermanistik ini didasarkan pada pemikiran Alois Wierlacher yang menyatakan adanya perbedaan orientasi dalam pengkajian Germanistik di negara-negara yang berbahasa Jerman dan negara-negara yang bukan berbahasa Jerman. Lebih jauh Alois Wierlacher mengemukakan bahwa di negara-negara yang tidak berbahasa Jerman hendaknya titik berat studi Germanistik lebih diarahkan pada masalah-masalah interkulturalisme (http://de.wikipedia.org/wiki/Germanistik). Selanjutnya, untuk mengukuhkan gagasan tersebut Wierlacher mendirikan jurusan Interkulturelle Germanistik di Universitas Bayreuth Jerman. Sementara kajian Interkulturelle Germanistik adalah membandingkan antara bahasa Jerman dan bahasa lain, dalam hal ini bahasa pembelajar bahasa Jerman. Dalam konteks ini, perbandingan yang dimaksud adalah perbandingan linguistik bahasa Jerman dan bahasa Indonesia (Widodo, 2011).

Salah satu masalah dalam pembelajaran bahasa asing adalah bahwa teks atau tuturan bahasa tersebut mengandung dua makna, yakni makna harfiah dan makna 
budaya. Seringkali para pembelajar bahasa asing (bahasa Jerman) kerap mengalami kesalahan dalam memahami sebuah tuturan karena kurangnya kompetensi budaya dari bahasa asing yang dipelajari. Pemahaman aspek budaya menjadi salah satu persyaratan terjadinya komunikasi antar budaya.

Pertemuan antar budaya dalam era globalisi tidak dapat dielakkan lagi karena karakter dari globalisasi adalah batas-batas antar negara sudah tidak terlihat lagi. Menurut Litvin (Mulyana, 2001) dunia sedang mengalami penyusutan sehingga memahami keanegaragaman budaya adalah sebuah keniscayaan. Lantas apa yang terjadi ketika dua budya atau lebih saling bertemu? Situasi akan menjadi buruk ketika komunikasi yang terbangun di antara dua elemen budaya bertemu tidak efektif. Masalah yang muncul dimulai dari hal yang kecil berupa kesalahpahaman dan yang terbesar adalah pertumpahan darah.

Bolten (2001:65-80) mendefinisikan pertemuan dua budaya atau lebih berarti hidup berdampingan (nebeneinander leben), hidup bersama-sama (miteinander leben) adanya interaksi dan inisiatif sosialisasi diri dari kedua pihak bahkan berujung menjadi proses akulturasi. Tugas interkultural adalah mendorong proses hidup berdampingan menjadi hidup bersama-sama.

Bahasa mencerminkan budaya sebuah bangsa karena setiap bahasa mencerminkan perilaku khas, kebiasaan khas, moral khas semua aktivitas khas lainnya dari bangsa tersebut (Soekanto, 1990). Dengan demikian, belajar bahasa asing pada dasarnya belajar budaya dari bahasa tersebut. Itulah sebabnya sering terjadi kesalahpahaman dalam berbahasa asing karena faktor budaya tidak diperhitungkan yang dapat memberi kekhasan makna. Di sinilah terjadi pertemuan dua budaya dalam belajar bahasa asing. Dalam situasi pertemuan dua budaya seperti itu diperlukan minimal dua kompetensi, yakni kompetensi interkultural dan komunikasi antarbudaya (Brown, 2008).

Istilah komunikasi interkultur dan yang terkait dengan sarana pengajaran dan penelitian mengarah pada dimensi komunikasi hubungan antara anggota/masyarakat budaya yang beragam (Nuenning, 2009:3). Istilah interkultural berarti antarbudaya. Ia mengacu pada interaksi atau komunikasi antara anggota dari sejumlah kelompok sosial atau budaya, semua bentuk inteksi dan komunikasi kemudian disebut interkultural (Oatey, 2009:22).

Berdasarkan pengertian di atas, yang dimaksud dengan tuturan interkultural bahasa Jerman adalah tuturan-tuturan bahasa Jerman yang bermuatan budaya Jerman baik secara implisit maupun eksplisit dan tuturan tersebut dapat memberikan dampak keterasingan (Fremdheit) ketika dikomunikasikan oleh pembelajar yang berlatabelakang budaya non Jerman. Sementara itu, pengertian budaya yang dipakai dalam penelitian ini merupakan gabungan dari berbagai pendapat pakar. Semua pakar budaya sepakat bahwa budaya merupakan sistem nilai, gaya hidup, kayakinan, aturan, adat-istiadat, serta semua kebiasaan yang didapat manusia sebagai anggota masyarakat dan diatur bersama oleh sebuah kelompok tetapi mempunyai peluang untuk berubah seiring waktu (Liliweri, 2009).

Ada kemungkinan berbagai istilah yang muncul sesuai dengan tema apa yang sedang diteliti, semisal muncul istilah interkultural dalam masalah makanan (Interkulturelles Essen). Istilah ini muncul dikarenakan ada tuturan yang terkait makan di Jerman yang menimbulkan keterasingan bagi pembelajar non Jerman karena adanya perbedan makanan antara yang ada di Jerman dengan yang ada di luar Jerman. Istilah lain yang muncul interkultur dalam pakaian (Interkulturelle Kleidung). Istilah ini muncul dikarenakan ada perbedaan cara berpakain antara 
orang Jerman dan orang non-Jerman. Di samping dua istilah di atas, masih banyak istilah lain seperti interkultural dalam kebiasaan (Interkulturelle Gewohnheit), interkultural dalam waktu (Interkulturelle Zeit), dan lain-lain

Benyamin L. Whorf (Pelz, 2002) menyatakan bahwa suatu realitas secara kebahasaan akan dipahami dengan cara yang berbeda-beda oleh berbagai masyarakat tutur. Oleh karena itu, seseorang hanya akan mengekspresikan sesuatu (realitas) sesuai dengan sarana kebahasaan yang tersedia di dalam (sistem) bahasanya. Itulah sebabnya, suatu realitas yang sama dimungkinkan secara kebahasaan dinyatakan dengan bentuk (dan makna) tuturan yang berbeda.

Sebagai contoh ungkapan yang digunakan seseorang ketika bertemu dengan kenalannya. Dalam situasi semacam itu seorang penutur bahasa Indonesia akan menggunakan satuan lingual Apa kabar? sebagai ungkapan yang dimaksudkan untuk menanyakan keadaan orang tersebut, sementara itu seorang penutur bahasa Jerman akan menggunakan ungkapan Wie geht es Ihnen. Kedua satuan lingul di atas, baik dari segi bentuk maupun makna harafiah, sangatlah berbeda. Oleh sebab itu, terjemahan secara harafiah dari kedua tuturan di atas tidak dapat saling dipertukarkan, karena akan menimbulkan pemahaman yang berbeda. Dalam bahasa Indonesia inti atau fokus dari ungkapan di atas berada pada kata kabar, sementara dalam bahasa Jerman berada pada kata gehen, yang bila diterjemahkan bermakna 'berjalan'.

\section{METODE}

Tujuan penelitian ini adalah mengindentifikasi tuturan-tuturan interkultural bahasa Jerman yang terdapat dalam buku ajar di perguruan tinggi. Berdasarkan tujuan tersebut maka dalam penelitian ini digunakan pendekatan deskriptif kualitatif dengan cara melakukan studi analisis tuturan bahasa Jerman dalam buku ajar di perguruan tinggi.

Sumber data penelitian ini adalah buku ajar (text book) bahasa Jerman Studio d $\mathrm{A} 1, \mathrm{~A} 2$, dan B2 sebagai buku ajar pokok (Funk, 2008). Lokasi penelitian di lakukan di dua tempat pertama di UNY Yogyakarta dan di jurusan interkulturelle Germanistik di Bayreuth Jerman.

Data yang akan diperoleh dari penelitian ini berupa tuturan-tuturan interkultural yang terdapat dalam buku ajar bahasa Jerman di perguruan tinggi. Untuk mendapatkan data-data tersebut dipergunakan sejumlah metode pengumpulan data seperti: simak (baca)-catat, dan observasi teks. Metode penyediaan data ini diberi nama metode simak karena cara yang digunakan untuk memperoleh data dilakukan dengan menyimak penggunaan bahasa baik secara tertulis maupun lisan. Metode ini mempunyai teknik dasar yaitu teknik sadap yaitu peneliti mendapatkan data dengan cara menyadap penggunaan bahasa baik secara tertulis maupun lisan lewat para informan. Teknik selanjutnya adalah teknik libat cakap yaitu peneliti terlibat langsung dalam proses dialog untuk mendapatkan data-data yang diperlukan (Sudaryanto, 1993).

Untuk mendapatkan data tuturan interkultural maka teknik pertama yang digunakan adalah metode simak (baca) yaitu dengan membaca dan menyimak buku ajar bahasa Jerman di perguurna tinggi. Dalam proses pembacaan dan penyimakan, peneliti memberi markah atau tanda tuturan-turan yang dikategorikan sebagai tuturan interkultural (Sudaryanto, 1993).

Untuk menganilis data dipergunakan teknik analisis analisis konten, analisis padan ekstralingual, dan deskriptif kualitatif. Analisis konten dilakukan untuk menganalisis isi tuturan-tuturan interkultural dalam text book buku ajar bahasa Jerman, analisis padan ekstralingual adalah untuk menghubungbandingkan dengan unsur yang berada di luar bahasa seperti makna, informasi, konteks tuturan. 


\section{HASIL DAN PEMBAHASAN}

Berdasarkan rincian tujuan penelitian, diperoleh temuan yaitu identifikasi tuturan-tuturan interkultural bahasa Jerman dalam buku ajar di perguruan tinggi. Temuan atau hasil penelitian berupa delapan aspek atau unsur tuturan tuturan bahasa Jerman yang mengandung unsur interkultural. Kedelapan aspek tuturan interkultural, yaitu makanan, pakaian, tempat tinggal, pernikahan, moral, tradisi, aturan, dan bahasa. Masing-masing aspek terebut kemudian dianalisis unsur budayanya dan dibandingkan dengan budaya Indonesia.

\section{Interkultural Tema Makanan}

Gambaran informasi interkultural berkaitan dengan tema budaya makanan seperti tampak pada kutipan di bawah ini.

Bei uns zu Hause kaufe ich Weissbrot. Bauernweissbrot (studio D a1:163)

Di Jerman saya (orang Jerman) membeli roti putih.

Kata Bauernweissbrot dan Weissbrot merupakan salah jenis roti dari berbagai jenis roti yang diproduksi di Jerman. Mereka mengenal berbagai kosa kata roti karena roti merupakan salah satu makan pokok yang dikonsumsi setiap hari. Berikut beberapa kosa kata yang terkait dengan roti yaitu 'Broetchen' (roti kecil), Kaesebroetchen (roti keju kecil). Di Berlin kata Broetchen dikenal dengan nama die Schrippe, die Hamburg das Rundstueck, di Jerman bagian selatan dan Austria di Semmel. Brot dan Broetschen adalah roti yang dikonsumsi orang Jerman saat makan pagi atau malam.

Sementara itu, di Indonesia roti belum menjadi makanan utama sehingga namajenis roti tidak sebanyak di Jerman. Dalam kehidupan sehari-hari, roti belum banyak menghiasi meja makan saat pagi, siang atapun malam. Namun, roti sudah men- jadi bagian budaya bagi kalangan tertentu seperti di kota-kota besar dan biasanya dari keluarga sibuk. Di Indonesia secara garis besar roti dibedakan menjadi dua roti kering dan roti basah. Roti kering di Jerman tidak disebut roti tetapi 'Kuchen', sedangkan roti basah mendekati pengertian 'Brot'.

Data (1.1.2)

Ich esse lieber Currywurst mit Pommes als Fisch (studio D a1:163)

Saya lebih suka makan sosis Curry dengan kentang goreng dan ikan.

Di samping roti atau Brot orang Jerman juga mengenal berbagai macam nama sosis. Salah satunya adalah Currywurst. Sosis juga termasuk jenis masakan yang digemari dan menjadi salah satu menu untuk makan pagi. Biasanya disajikan bersama roti, keju, dan kopi atau teh. Berikut nama-nama jenis sosis yang lain Wurstbrot, Schnittwurst, Streichwurst, Wuerstchen, Wuerstchenbunde, Wuerstchenstand, dan Bratwuerstchen. Jenis-jenis sosis ini menjadi sulit untuk dipahami seperti apa wujud barangnya karena di Indonesia tidak dikenal berbagai istilah tersebut. $\mathrm{Di}$ Indonesia terdapat dua macam sosis yang dikenal sosis ayam dan sosis sapi.

Roti dan sosis merupakan makanan yang sangat digemari di Jerman sementara di Indonesia kedua makanan tersebut hanya menjadi pelengkap. Itulah sebabnya, banyak kosa kata yang terkait dengan kedua kata tersebut muncul di Jeman. Variasi kota tersebut kemudian menjadi asing bagi pembelajar Indonesia karena kosa kata tersebut tidak ditemukan di Indonesia. Orang harus menghubungkan dengan budaya makan orang Jerman untuk memahami dengan benar kosa kata tersebut.

\section{Interkultural Tema Pakaian}

Gambaran informasi interkultural berkaitan dengan tema budaya pakaian 
seperti tampak pada kutipan di bawah ini.

Mit Jeans in die Oper gehen, obwohl Ihrle Patner/in sich besonders schoen kleidet (1:122)

Anda pergi menonton opera dengan berpakaian Jeans padahal pasangan anda berpakaian resmi (istimewa)

Secara historis pertunjukan opera atau konser sebenarnya diperuntukkan para bangsawan atau orang-orang terkemuka dan terpandang. Saat itu orang yang hadir menyaksikan tentunya berasal dari golongan orang tersebut. Mereka terbiasa berpakain resmi dan mewah selayaknya seorang bangsawan atau orang terpandang. Tradisi berpakain seperti itu hingga kini masih melekat pada diri masyarakar Jerman walaupun pertunjukan opera tersebut sudah menjadi konsumsi publik. Akan menjadi aneh tentunya apabila mereka menyaksikan pertunjukkan tersebut dengan memakai jeans dan T-Shirt.

Demikian juga ketika orang bepergian ke teater juga berpakaian resmi seperti jas untuk laki-laki dan gaun malam untuk perempuan. Seperti dalam tuturan interkultural di bawah ini:

Data (1.2.2)

Maenner gehen am besten im Anzug und Frauen im Abendkleid ins Theater (Studio d B11:128)

Laki-lai pergi ke teater mengenakan jas dan perempuan mengenakan gaun malam.

Tradisi berpakain seperti itu sangat berbeda dengan di Indonesia. Mereka bebas untuk memilih pakain yang akan dikenakan ketika akan pergi ke teater, konser atau opera. Justru sebaliknya pada umumnya mereka cenderung berpakain santai tidak resmi kecuali tamu undangan, yang mengenakan baju agak resmi seperti batik

\section{Interkultural Tema Mata Pencaharian (Pekerjaan)}

Gambaran informasi interkultural berkaitan dengan tema mata pencaharian (Interkultureller Beruf) seperti tampak pada kutipan di bawah ini.

In Deutschland ist der Lieblingsberufvon Frauen Kauffrau. An zweiter stelle steht bei Frauen Arzthelferin. Dann komm Frisoerin. Der Traumberufvon Maennern ist Automechaniker. Viele junge Maennerr moechten auch Kaufmann werden. An drittel stele steht Elektriker. (Studi D a1:123)

Di Jerman pekerjaan impian para wanita pertama adalah pengusaha, kedua perawat, ketika pemotong rambut, sedangkan untuk laki-laki pertama adalah mekanik mobil, pengusaha, dan pekerjaan yang terkait dengan elektonika (montir listrik).

Teks di atas menggambarkan impian pekerjaan yang didambakan oleh orang Jerman berdasarkan perbedaan jenis kelamin. Data tersbut merupakan hasil survei. Berdasarkan hasil survei tersebut dapat dikatakan bahwa orang Jerman memiliki kemandirian hidup dengan dipilihnya pengusaha sebagai impian pekerjaan yang pertama bagi perempuan dan kedua bagi laki-laki.

Hal yang menarik adalah bahwa pekerjaan menjadi pemotong rambut ternyata menjadi salah satu impian pekerjaan orang Jerman. Jika dibandingkan dengan impian pekerjaan kebanyakan orang Indonesia, maka impian pekerjaannya adalah pertama menjadi pegawai negeri dan jarang mereka mimilih menjadi pengusaha dan menjadi pemotong rambut bukan menjadi pekerjaan yang prestisius bagi orang Indonesia.

Dari data tersebut dapat disimpulkan bahwa orang Jerman lebih memiliki kemandirian dalam hidup ketimbang orang Indonesia. Kemandirian ini juga dapat 
dilihat dalam aktivitas mereka dalam berbagai kehidupan. Dalam belajar misalnya, mereka sangat mandiri mencari bahan dan sumber belajar. Mereka menjadikan perpustakaan sebagai tempat yang tepat untuk mencari sumber belajar. Mereka datang di kelas dengan sejumlah bahan siap untuk melakukan diskusi dan berargumentasi.

Contoh lainnya adalah orang Jerman lebih suka membaca daripada bertanya. Mereka terbiasa membaca peta dan informasi dalam buku sebelum melakukan perjalanan sehingga mereka benar-benar bertanya sebuah informasi jika mereka tidak menemukan dalam bacaan.

\section{Interkultural Tema Sistem Perkawinan}

Gambaran informasi interkultural berkaitan dengan tema sistem perkawinan antarbudaya (Interkulturelle Heirat) seperti tampak pada kutipan di bawah ini.

Wir sind jetzt seit acht Jahren zusammen, aber nicht verheiratet. Ich bleibe mit Peter zusammen'

Kami telah hidup bersama selama delapan tahun tanpa menikah. Saya tinggal bersama Peter. (Studio d B1:49)

Tuturan di atas merupakan ujaran yang sangat biasa dialami dan dilakukan dalam masyarakat Jerman. Tinggal bersama tanpa ikatan pernikahan bukan merupakan hal yang tabu dan dipersoalkan oleh masyarakat. Bagi mereka seks merupakan masalah pribadi dan bebas dilakukan asal ada kesepakatan dan bukan dari paksaan. Dampaknya iklaniklan yang berbau seks bebas ditayangkan di berbagai media. Mereka menjadikan seks sebagi bagian dari industri untuk mendapatkan kapital. Walaupun seks bebas mereka dibatasi oleh umur. Orang dengan umur di atas 17 tahun yang boleh mendapatkan kebebasan ini.

Di Indonesia perkawinan merupakan peristiwa sakral karena menyangkut masalah agama dan agama masih menjadi bagian dari pandangan hidup yang paling penting. Oleh karena itu, perkawinan antar agama (bebeda agama) khususnya dalam agama Islam akan menjadi masalah tersendiri karena agama ini tidak memperbolehkan seorang yang beragama Islam menikah dengan orang yang bukan beragama Islam. Karena masalah perkawinan masih dianggap sakral oleh masyarakat Indonesia, hidup bersama tanpa ada ikatan perkawinan dianggap tabu dan melanggar norma agama.

Dengan demikian hal-hal yang berbau pornografi sangat tabu untuk dijadikan konsumsi umum dan terbuka. Iklan, foto, film dan sebagainya harus bersih dari unsur-unsur pornografi.

Tema perkawinan juga berkaitan dengan pemahaman masyarakat Jerman terhadap anak dalam keluarga. Masyarakat Jerman memiliki padangan dan pemahaman tersendiri menyangkut kedudukan anak dalam keluarga. Kutipan di bawah ini dapat menjelaskan anggapan tersebut.

Deutschland hat zu wenig Kinder. Viele junge Leute wollen keine Kinder, weil sie andere Prioritaeten haben: Ausbildung, Beruf, Freizeit. Die Verbindung von Familien und Beruf ist fuer Maenner und Frauen schwer. Es gibt zu wenig Plaetze in Kindergaerten und die Oeffnungszeiten sind fuer Menschen im Beruf Problematisch.(Studio d A2:27) Jerman mempunyai sedikit anakanak. Banyak kaum muda tidak mau mempunyai anak karena mereka mempunyai prioritas lain seperti pendidikan, pekerjaan, dan waktu luang. Hubungan antara keluarga dan pekerjaan bagi laki-laki dan perempuan merupakan hal yang sulit. Tempat untuk taman kanak-kanak terlalu sedikit dan waktu luang saat bekerja juga menjadi masalah. 
Teks di atas menggambarkan bagaimana sikap dan pemikiran orang muda Jerman dalam memandang pernikahan dan anak. Dengan berbagai alasan mereka seolah-olah sepakat untuk tidak mempunyai anak. Bagi mereka anak bisa menganggu privasi mereka. Mereka lebih mementingkan pendidikan, dengan pendidikan mereka akan mendapatkan pekerjaan, dengan pekerjaan itu mereka mendapatkan uang, dengan uang mereka juga dapat pergi melepaskan kepenatan dengan berlibur. Untuk mengatasi masalah ini pemerintah kemudian memberi himbauan akan pentingnya mempunyai anak lewat iklan-iklan.

Bagi orang Indonesia menikah adalah mempunyai anak atau keturunan. Karena dengan mempunyai anak maka ada regenarasi keluarga. Dari pandangan ini kemudian muncul pendapat bahwa jika seorang tidak mempunyai anak setelah menikah mereka berusaha mencari tahu sebab musababnya. Artinya, orang sangat serius dan manjadikan anak prioritas utama dalam setiap perkawinan.

Itulah sebabnya banyak sebuah pasangan pernikahan bercerai karena dari mereka tidak dapat mempunyai anak. Bagi orang Indonesia bekerja, kesuksesan, uang atau kekayaan akan digunakan untuk kebahagiaan anak. Kalau mereka tidak mempunyai anak untuk apa semua kekayaan ini. Bahkan mereka tidak berpikir untuk anak tapi sudah melesat kedepan mengarah ke cucu. Istilah yang sering muncul adalah demi anak dan cucu.

\section{Interkultural Tema Kebiasaan (Interkul- turelle Gewohnheit)}

Dari unsur budaya kebiasaan ditemukan tema kebiasaan dalam menggunakan waktu (Interkultureller Umgang mit der Zeit), tema kebiasaan mengisi waktu luang (Interkulturelle Freizeit). Kutipan data berikut ini sebagai penjelasan.
Der Zeitdruck, die Lernzeit, die Lebeszeit, die Wartezeit, die Arbeitszeit, die zeitpunkt, die Zeitplan, die Uhrzeit, die Halbzeit, die Freizeit, dan zeitlos (studio d B1 Hal:12)

Data di atas adalah sederetan frase yang lazim digunakan oleh orang Jerman untuk mengungkapkan konsep waktu. Munculnya istilah-istilah tersebut tidak lepas dari kebutuhan mereka untuk mengekpresikan tuturan, peristiwa atau tindakan yang terkait dengan waktu. Orang Jerman mempunyai kebiasaan tepat waktu. Kebiasaan tersebut dikenal dengan istilah 'Deutsche Punktlichkeit' (Orang Jerman tepat waktu). Mereka sangat menghargai waktu. Waktu digunakan dengan tepat dan efektif seolah-olah waktu selalu mengejar dan mereka selalu kekurangan waktu untuk melakukan aktivitas (Der Zeitdruck). Semangat ini mereka wujudkan dalam berbagai kegiatan baik yang bersifat pribadi ataupun yang menyangkut hajat hidup orang banyak. Semisal bagaimana mereka menerapkan konsep waktu dengan detail dan tepat waktu dalam realisasinya dalam mengatur transportasi kereta api dan bus kota. Sistem diatur dan direncanakan mulai kapan kereta api berangkat, waktu yang dibutuhkan sampai tujuan dan bahkan setelah sampai di stasiun tujuan bagi yang akan melanjutkan perjalanan tersedia pilihan-pilihan rencana perjalanan yang sudah diatur waktunya dengan koneksi bus atau yang lain, berapa lama waktu perjalanan dengan jalan kaki dari stasiun ke halte bus, jam berapa bus yang paling cepat dapat digunakan.

Dalam kehidupan sehari-hari mereka juga menerapkan waktu dengan tepat. Mereka terbiasa memulai kegiatan seperti bekerja, rapat, janjian, dan lain-lain dengan tepat waktu dan tidak mudah begitu saja untuk membatalkannya. Itulah sebabnya mereka banyak menuturkan penggunaan waktu dengan tuturan-tuturan 
khusus dan mengandung budaya waktu yang sangat mereka hargai.

Entschuldigen Sie, wie spaet ist es bitte? (Studio D a1:83)

Mohon maaf, jam berapakah sekarang?

Ada banyak cara orang Jerman untuk bertanya tentang waktu. Salah satu cantohnya adalah 'wie viel Uhr ist es ?' dan 'wie spaet ist es bitte?'. Kalimat wie viel Uhr ist es merupakan kalimat yang biasa dan orang mudah untuk memahaminya bahwa kalimat tersebut bermaksud menanyakan waktu atau jam. Sedangkan dari kalimat 'wie spaet ist es bitte? Orang kesulitan untuk memahaminya secara harfiah karena kata 'spaet' secara harfiah berarti terlambat. Dengan demikian arti kalimat tersebut dapat diartikan secara harfiah 'seberapa terlambat'. Jika kalimat tersebut diartikan seperti itu maka kalimat tersebut akan kehilangan makna yang sebenarnya. Orang harus melihat konteks budaya dari kalimat tersebut. Dalam kontek budaya orang Jerman, kalimat tersebut bermakna bahwa mereka sangat menghargai waktu, disiplin waktu, selalu berusaha tepat waktu dalam semua aktivitas sehingga mereka takut terlambat. Itulah sebabnya mereka menggunakan kalimat tersebut untuk menanyakan waktu atau jam.

Di Indonesia juga ada beberapa cara orang untuk menanyakan waktu dengan menggunakan kata jam atau diawali dengan kata kapan. Seperti 'Jam berapa? Atau pukul berapa? Yang dalam bahasa Jerman diartikan 'wie viel Uhr ist es?'. Sebenarnya banyak orang Indonesia sudah merasakan betapa pentingnya disiplin waktu. Namun kesadaran tersebut belum membudaya secara merata, baru dilaksanakan di beberapa kalangan dan kebanyakan secara pribadi-pribadi. Mengingat budaya Jerman yang sangat menghargai waktu maka orang Indonesia seharusnya berusaha semaksimal mungkin untuk dapat memahami budaya tersebut dan berusaha untuk belajar tepat waktu dan menghargai waktu ketika berinteraksi dengan mereka. Demikian pula sebaliknya dikarenakan orang Indonesia belum mempunyai budaya tepat waktu maka orang Jerman harus memahami oang Indonesia ketika terjadi keterlambatan dalam berbagai aktivitas baik menyakngkut pribadi ataupun bersifat umum. Orang Jerman harus memaklumi ketika diundang pukul 08.00 ternyata acara baru mulai pukul 08.30 atau bahkan jam 09.00.

\section{Interkultural Tema Moral (Interkulturelle Moral)}

Dari unsur budaya moral ditemukan tema sopan santun (Interkulturelle Höflichkeit). Kutipan berikut menjelaskan fenomena tersebut.

Sich im Restaurant an einen Tisch setzen, obwohl dort schon leute sitzen (1:122) Data (5.1.1)

Duduk di sebuah tempat duduk di restaurant walaupun di tempat tersebut telah banyak orang yang duduk.

Dalam kebiasaan orang Jerman adalah tidak sopan apabila seseorang tiba-tiba duduk di meja di sebuah restauran padahal di tempat tersebut telah ada pasangan lain. Walaupun sebenarnya tidak ada aturan baku yang mengaturnya namun lebih baik tidak dilakukan. Namun pada siang hari di sebuah kantin orang boleh duduk bersebelahan dengan orang lain namun pada malam hari nampaknya tetap tidak dianggap tidak sopan. Kebiasaan ini tidak lepas dari karakter orang Jerman yang senang dalam kesunyian dan tidak senang kegaduhan. Itulah sebabnya, mereka akan terganggu seandainya tibatiba ada orang menyelonong duduk di sebelahnya atau di sekitarnya karena akan terganggu privasinya. Sikap ini terkait dengan cara pandang tentang kesopanan (Hoeflichkeit) 
Data (5.1.2)

In der Kneipe das Geld auf den tisch legen und gehen, obwohl der Kellner es nicht gesehen hat (Studio d B11:122)

Meninggalkan uang makan/minum di meja dan pergi walaupun pelayan tidak melihatnya.

Tradisi membayar makanan dan minuman dengan cara meninggalkan uang di atas meja tanpa sepengetahuan pelayan merupakan budaya orang Italia. Di Italia tindakan seperti ini dianggap tidak bermasalah. Namun di Jerman cara seperti ini dianggap tidak baik dan perlu dihindari. Lebih baik membayar langsung di atas meja dengan memanggil pelayan.

Bagi orang Indonesia cara membayar dengan meninggalkan uang di tas meja juga belum dikenal sehingga tindakan ini dianggap tidak sopan dan dikira tidak bertanggung jawab dan melarikan diri.

Data (5.1.5)

Sie sind in Bayern und alle begruesen Si emit 'Gruess Gott". Solten Sie mit "Guten Tag" anworten? (Studio d B11:131)

Anda di Negara bagian Bayern dan semua orang menyapa anda dengan' Gruess Gott'. Apakah anda akan menjawab dengan "Guten Tag"?

Frase 'Gruess Gott' adalah ucapan selamat yang diucapkan oleh orang-orang di daerah Negara Bayern. Sebagai orang di luar Bayern apakah kita akan menjawab dengan Gruess Gott' juga atau dengan Guten Tag". pertanyaan ini merupakan pertanyaan yang sulit dijawab oleh orang non-Bayern apalagi oleh orang Indonesia jika budaya Bayern tidak dipahami.

\section{Interkultural Tema Tradisi (Interkul- turelle Sitte)}

Dari unsur budaya tradisi ditemukan tema tradisi di sekolah (Interkulturelle Schule), tema tradisi perayaan (Interkulturelles Feste und Feirtage). Penjelasan tentang tema tersebut sebagai berikut.
Am ersten Schultag bekommen die Kinder von ihren Eltern eine Schultuete. In der bunten Tuete aus pappe sind Suessigkeiten und Spielzeug, oder auch sachen, die die Kinder in der Schule brauchen, versteckt. In vielen Familien wird der erste Schultag mit Freunden und Verwandten gefeiert. (Studio d B1:79)

Pada hari pertama masuk sekolah, anak-anak mendapatkan Schultuete (hadiah yang dibungkus dari kertas karton). Di dalamnya terdapat makanan serba manis (coklat dan sejenisnya) dan mainan. Biasanya keluarga merayakannya dengan mengundang sanak saudara.

Dalam teks di atas terdapat dua tradisi yang menarik yang dilakukan oleh sebuah keluarga dalam menyambut anak-anaknya pergi ke sekolah untuk pertama kalinya. Tradisi tersebut yaitu pemberian hadiah kepada anak yang pertama kali akan pergi sekolah berupa 'Schultuete' dan perayaan di keluarga dengan mengundang sanak saudara. Ini adalah tradisi yang dilakukan oleh orang Jerman. Mereka benar-benar menyiapkan anak-anaknya untuk siap bersekolah. Schultuete berupa bungkusan memanjang yang terbuat dari kertas tebal dan berisi makan kesukaan anak-anak dan mainan serta peralatan sekolah. Makanan serba manis seperti coklat mempunyai tujuan agar anak-anak mereka dapat merasakan manisnya bersekolah seperti mereka makan coklat. Sementara itu, mainan (Spielzeug) mempunyai tujuan agar mereka merasakan bahwa bersekolah adalah suatu hal yang menyenangkan. Kegiatan perayaan dimaksudkan sebagai sebuah persiapan mental bagi anak-anak bahwa semua keluarga mendukungnya dan mereka tidak merasa sendirian.

Itulah sebabnya di Jerman konsep yang dipakai dalam taman kanan-kanak adalah bermain. Kalaupun mereka belajar sesuatu seperti bahasa asing tetap dengan bermain. Fokus pendidikannya 
adalah pengembangan kepribadian dan karakter. Bagaimana mereka berlatih berorienteraksi sosial dengan temantemannya, sehingga mereka siap nantinya melakukan interaksi ketika memasuki sekolah dasar.

Di Indonesia belum ada tradisi khusus dalam mempersiapkan anak-anaknya yang akan masuk sekolah untuk pertama kalinya. Persiapan apa yang akan dilakukan semuanya diserahkan kepada masingmasing keluarga. Biasanya mereka hanya diajak di toko dan dibelikan alat-alat tulis dan tas namun persiapan mental belum banyak dilakukan. Konsekuensinya biasanya orang tuanya harus menunggu di sekolah sampai anak-anaknya mau ditinggal.

\section{Interkultural Aturan (Interkulturelles Gesetzt)}

Dari unsur budaya aturan ditemukan tema aturan membuang sampah, aturan lalu lintas, aturan sistem tiket (Interkulturelles Fahrkartesystem)

Sie fahren mit dem Auto. Ein Polizist haelt Sie an, weil Sie zu schnell gefahren sind. Sie entsschuldigen sich und sagen, dass Ihre Tochter ein Kind bekommt. Sie muessen ins Krankenhaus. Sie muessen 40 Euro zahlen und eine Quittung unterschreiben.Der Polizist wuenscht Ihnen viel Glueck. (Studio d B1:31)

Anda mengendarai mobil dan seorang polisi menghentikan Anda karena berjalan terlalu cepat. Anda minta maaf karena anaknya melahirkan dan Anda harus ke rumah sakit. Anda harus membayar 40 Euro dan menandatangani kuitansi. Polisi tersebut mendoakan semoga Anda mendapatkan banyak keberuntungan.

Cerita di atas adalah ketegaran seorang polisi dalam mejalankan tugas. Dia tidak terpengaruh oleh apapun termasuk situasi orang yang sedang dia tangani. Pelanggaran adalah pelanggaran. Dia tidak mentolelir alasan apapun untuk menghindar dari kesalahan. Di sini terlihat budaya Jerman yang berorientasi pada aturan. Orang harus taat pada aturan.

Eine Reise planen und buchen.

- Guten Tag. Zwei Fahrkarten nach Budapest, bitte. Hin und Zueruck.Wie teuer sind den die Fahrkarten?Selamat siang, dua tiket ke Budapes pulang pergi, berapa harganya?

- Pro Person 180,72 Euro. Soll ich die Verbindung ausdrucken? Setiap orang 180,7 Euro, apakah tiket perlu di cetak?(Studi d A2:40)

Dialog di atas terjadi antara seorang yang sedang memesan dengan seorang petugas bagian tiket. Hin und Zueruck istilah tiket yang menunjukkan tiket pulang pergi. Di Jerman tiket pulang pergi jauh lebih murah daripada tiket pulang saja atau pergi saja. Ada banyak fasilitas yang sangat memudahkan dan menguntungkan pelanggan selain tiket Hin und Zueruck, misalnya tiket perseorangan atau grup. Tiket perseorangan hanya berlaku untuk satu orang sedangkan tiket grup berlaku untuk 5 orang. Tiket perseorangan jauh lebih mahal daripada tiket grup. Ada juga tiket lain yang hanya berlaku di sebuah Negara bagian semisal Bayern Tiket adalah sebuah tiket yang berlaku selama 24 jam dan dapat digunakan baik perseorangan ataupun grup. Tiket ini dapat digunakan untuk kereta api dan bus. Bahkan tiket kereta api dapat digabungkan menjadi satu dengan tiket pesawat. Semisal dari kota Bayreuth menuju bandara Muenchen dan terbang ke Indonesia. Maka tiket kereta api dan bus kota dari Bayretuh ke Munchen sudah menjadi satu dengan tiket pesawat. Fasilitas lain yang sangat menguntungkan adalah tentang harga. Para pelanggan dapat menikmati liburan akhir pekan dengan biaya yang efisien karena saat liburan justru harga tiket lebih murah. 
Dalam tuturan di atas ada frase die Verbindung ausdrucken (mencetak tiket). Perlu diketahui bahwa pemerintah Jerman menyediakan tiga cara untuk mendapatkan sebuah tiket. Pertama bisa lewat internet. Orang dapat langsung mencetak tiket, kedua lewat mesin otomatis, dan ketiga lewat petugas tiket di kantor. Untuk pembelian tiket via internet dan mesin otomatis pelanggan dapat menikmati fasilitas harga yang lebih murah daripada membeli langsung di petugas. Adanya peran petugas dalam melakukan pekerjaan maka tiket lebih mahal sedikit. Dalam tiket sudah tertera dengan jelas dan detail waktu sampai menit, di mana orang harus pindah kereta, jam berapa orang harus menunggu kereta, dan berapa lama orang jalan kaki dari stasiun menuju halte bis terdekat. Semua terkait dengan persolan waktu yang serba efisien dan tepat waktu.

\section{Interkultural Berkaitan dengan Bahasa (Interkulturelle Sprache)}

Tata bahasa Jerman dan Indonesia sangatlah berbeda. Inilah yang menyebabkan pembelajar Indoensia sering banyak mengalami kesulitan atau bahkan kesalahan. Ketika mempelajari bahasa Jerman kebanyakan pola pikir yang dipakai adalah sisitem bahasa Indonesia sehingga yang muncul kemudian adalah menerjemahkan bagaimana cara mengungkapkan kata/kalimat bahasa Indosneia ini dalam bahasa Jerman. Proses ini memakan waktu yang lama karena mereka harus berpikir dua kali. Pertama berpikir dalam bahasa Indonesia baru kemudian dalam bahasa Jerman. Peristiwa seperti ini dapat diminimalisir ketika seorang belajar bahasa Jerman sebagai bahasa asing orang sudah terlebih dahulu memahami perbedaanperbedaannya.

Ada beberapa perbedaan tata-bahasa Jerman dan Indonesia. Pertama, perbedaan der Artikel. Der Artikel adalah ciri penanda kata benda apakah itu berjenis kelamin laki-laki, perempuan atau netral (interkulureller Artikel). Kedua, dalam bahasa Jerman kata kerja harus diletakan dalam posisi kedua dalam sebuah struktur kalimat kecuali ada sebab tertentu sehingga sebuah kata kerja harus diletakkan pada bagian paling belakang (interkulturelle Verbstellung). Dengan demikian objek dapat diletakkan dalam posisi pertama baru diikuti kata kerja. Ketiga, setiap kata kerja mempunyai valensi yang bermacam-macam sehingga makna sebuah kata kerja sangat tergantung konteksnya. Keempat, ada tiga macam preposisi yang masing-masing mempengaruhi setiap kasus (interkulturelle Präposition). Kelima, setiap kata kerja mengalami perubahan bentuk sesuai dengan subjeknya (interkulturelle Konjugation). Keenam, setiap kata sifat mengalami deklinasi atau perubahan akhiran sesaui dengan kasusnya (interkulturelle Adjektivdeklination) (Widodo, 2009)

\section{SIMPULAN}

Berdasarkan hasil penelitian dan pembahasan disimpulkan sebagai berikut. Pertama, ditemukan delapan aspek interkultural tuturan bahasa Jerman dalam buku Studio d A1, A2, dan B1. Delapan aspek interkultural tersebut adalah interkultural dalam hal makanan, pakaian, tempat tinggal, kebiasaan, sistem pernikahan, moral, dan bahasa. Kedua, ditemukan perbedaan budaya antara Jerman dan Indonesia dalam delapan aspek tuturan interkultural tersebut, yaitu ada perbedaan jenis makanan, ada perbedaan jenis pakaian, ada perbedaan jenis tempat tinggal, ada perbedaan jenis dalam melakukan kebiasaan, adanya perbedaan dalam hal pernikahan, moral, dan bahasa. Ketiga, ada beberapa sebab yang dapat membedakan delapan aspek interkultural, yaitu perbedaan musim, perbedaan dalam makanan pokok, perbedaan dalam ideologi (agama), perbedaan sistem bahasa, perbedaan dalam tingkat kesejahteraan, dan 
perbedaan sejarah bangsa. Keempat, faktor pengetahuan terhadap budaya Jerman menjadikan pemahaman terhadap setiap tuturan interkulturan lebih mendekati ketepatan dalam hal makna dan mengurangi kesalahpahaman dalam berkomunikasi.

\section{UCAPAN TERIMAKSIH}

Penelitian ini dapat terselenggara dikarenakan bantuan oleh beberapa pihak. Untuk itulah kami ingin mengucapkan terimakasih, pertama kepada LPPM UNY yang telah menyeponsori penelitian ini dan memberi dana kepada kami dalam Skim Kerjasasama Internasional tahun 2011. Kedua kepada Dr. Peter Kiesler Mitra kami di Universitas Bayreuth Jerman yang telah bersedia menjadi patner penelitian. Ketiga kepada dosen dan mahasiswa Bahasa Jerman UNY serta kepada semua pihak yang tidak dapat kami sebut satu per satu. Harapan kami penelitian ini akan dapat dikembangkan lebih mendalam dan memberikan manfaat bagi segenap kalangan civitas akademika.

\section{DAFTAR PUSTAKA}

Bolten, Jurgen. 2001. Interkulturelle Kompetenze, Landeszentrale fuer Politische Bildung. Thuringen

Brown, Douglas. 2008. Prinsip Pembelajaran Bahasa dan Pengajaran Bahasa. Kedubes AS Jakarta: Pearson Education,Inc.

Engel, Urlich. 1991. Deutsche Grammatik. Heidelberg: Julius Groos Verlag.

Funk, H., Kuhn, C., Demme, S., Bayerlein, O. Winzer, B., Christiany, C. 2008. Studio $d$ A 1. Kursbuch. Jakarta: Katalis.
Funk, H., Kuhn, C., Demme, S., Bayerlein, O. Winzer, B., Christiany, C. 2008. Studio d A 2. Kursbuch. Jakarta: Katalis

Funk, H., Kuhn, C., Demme, S., Bayerlein, O. Winzer, B., Christiany, C. 2008. Studio d B 1. Kursbuch. Jakarta: Katalis

Glück, Helmut \& Sauer, Wolfgang Werner. 1997. Gegenwartsdeutsch. Stuttgart: Verlag J.B. Metzler.

Liliweri, Alo. 2009. Dasar-dasar Komunikasi Antarbudaya. Yogyakarta: Pustaka Pelajar

Matsumoto, D.1996. Culture and Psychology. Pacific Grove,CA: Brooks/Cole.

Mulyana, Deddy. 2006. Komunikasi Antarbudaya. Rosda. Bandung

Nuenning, Nuenning.2003. Konzepte der Kulturwissenschaften. J.B Metzler. Stuttgart

Oatey, Franklin. 2009. Intercultural Interaction. palgrave Macmillan.London

Pelz, Heidrun. 2002. Linguistik. Eine Einführung. Hamburg: Hoffmann und Campe.

Soekanto, Soerjono. 1990. Sosiologi Suatu Pengantar. Jakarta: CV Rajawali

Sudaryanto, 1993. Metode dan Aneka Teknik Analisis Bahasa. Yogyakarta: Duta Wacana University Press.

Widodo, Pratomo. 2009. “The Experiencer Role in German and Indonesians Sentences". Dalam Jurnal Kajian Linguistik dan Sastra. Volume 21, Nomor 1, Juni 2009. Universitas Muhammadiyah Surakarta. Halaman 34-48.

Widodo, Pratomo. 2011. “Germanistik dan Profesionalitas Guru Bahasa Jerman". Pidato Guru Besar Universitas Negeri Yogyakarta. 